according to the utilitarian or the intuitive theory of morality.

Such vagaries as the above are however rare, and we can conscientiously recommend this book as admirably adapted to lead its readers to observe for themselves the varied phenomena presented by insects, and thus to become true entomologists.

ALFRED R. WALLACE

\section{AMERICAN GEOLOGY}

Preliminary Field Report of the United States Geological Survey of Colorado and Nize Mexico. Conducted under the authority of the Hon. J. D. Cox, Secretary of the Interior. By F. V. Hayden, United States Geologist. 8vo. pp. 155. (Washington: Gorernment Printing Office, I 869.)

THIS preliminary field report makes us acquainted with a vast tract of territory hitherto scarcely known, save to the more adventurous squatters and to the various tribes of Indians who have gradually been driven farther and farther west by the wonderful growth of the United States populations, fed as they are annually by streams of English, Irish, Scotch, and German emigrants. Unfortunately for the Red-skins, they are not only hemmed in on the one side by the United States, and on the other by the equally vigorous growth of California and its vast mining and agricultural population; but their territory, only hitherto invaded by the Mormons and the "PonyDispatch," is now cut in twain by the great Pacific Railroad, which, in its course, has sent forth geological reconnaissances right and left, discovering timber here, coal there, building stone in this spot, mines in that, until there is no space left for them save in the happy hunting. grounds above, to which they are fast going, aided by revolvers, alcohol, and disease.

The report refers to a line of country extending from British North America to New Mexico in a northerly and southerly direction, and from the Rocky Mountains to the Lower Missouri in an easterly and westerly one. Di: Hayden explains the reason why he has been able in a very short time to cover so large a tract of territory-it is, that "there is great uniformity in the geology of the country, and when one has become familiar with the different geological formations over a small area, he can trace them with great rapidity over long distances" (p. II).

First, we have the Rocky Mountain system forming the main ridges and the hills, composed of granite rocks. Resting on the flanks of these more elevated masses, the stratified deposits are exposed in succession, becoming less and less inclined as we recede from them and enter the plains.

The oldest stratified deposit met with is the Potsdam Sandstone, equivalent in geological position to our Upper Cambrian, or to the Primordial Zone of Barrande ; this is followed by strata of Carboniferous age, but giving no promise of workable seams of coal. The Triassic series may be represented by certain red arenaceous deposits, sometimes containing gypsum and rocksalt; these pass upwards into undoubted Oolitic beds. Next follows a Cretaceous formation, some 4,000 feet in thickness, followed by a well-developed Tertiary series of vast geographical extent, and but very slightly inclined.
These Tertiary beds are rich in lignites, and evidence a long period of tranquil estuarine or lacustrine deposition in a region supporting dense forests of large trees, and a vegetation far exceeding in luxuriance anything now met with in these latitudes. Carnivores, Pachyderms, Proboscidea, \&c., occur in great abundance. It is very interesting to know that in Tertiary times North America had its elephants, hippopotami, rhinoceroses, horses, lions, \&c., and was, in the size and abundance of its Mammalia, in no way surpassed by the Continents of the Old World.

Two minor reports accompany Dr. F. V. Hayden's reyort, one on "Mines and Mining," by Mr. Persifor Frazer, jun., giving a most interesting account of the mining capabilities of the district; the other on the "Agriculture of Colorado," by Mr. Cyrus Thomas. There is every prospect of the Colorado territory becoming as rich an agricultural district as it has already proved to be a mining one.

H. W.

\section{OUR BOOK SHELF}

Aunt Rachel's Letters about Water and Air. (London: Longmans and Co., $187 \mathrm{I}$.)

IN the form of a series of familiar letters from an aunt to a nephew and niece, we have here an account, in simple famlliar language, of some of the commoner physical phenomena of nature. Recollecting the books with a similar aim that have passed through our hands, we feel grateful to find one free from conspicuous blunders. To the little book before us we need not however apply such negative praise. It is in all respects to be commended as a book to put into the hands of the young. And we fancy that even many well-educated people who are not young in years, will find a record and explanation of facts with which they are rot familiar. They may learn here all about the formation of ice, latent and specific heat, the air-pump, the barometer and thermometer, the winds, combustion, and many other pheromena of daily life. A few well.executed woodcuts illustrate the text; and we would like to hear that a large circulation has rewarded the efforts of "Aunt Rachel" to popularise the elements of science.

Handbuch der allgemeinen Himmelsbescheibung vom Stancipunkte der kosmischen $\boldsymbol{W}$ eltanschaunng dargen. stcllt. Von Hermann J. Klein. Pp. 35r. (Braunschweig, 1871. London: William and Norgate.)

Theoretische Astronomie. Von Dr. W. Klinkerfues. Erste Abtheilung. Pp. 256. (Ditto, ditto.)

THE first of these works is the second edition of the first part of a general description of the universe, and is devoted to the solar system : another part will be given to the fixed stars. The aim of the author is to afford a complete account of his subject, including the latest researches, which shall be at the same time thoroughly scientific, while it will not be beyond the comprehension of those who are possessed of only an elementary knowledge of astronomy, or more properly perhaps urancgraphy. The first forty-nine pages contain a description of the sun; the next five are given to the zodiac. Then follow the planets Mercury, Vinus, \&c., in order, ard finally we have a full and very interesting account of comets and meteorites.

Turning to the chapter on the sun, we find, after a general introduction, methods for calculating the distance between the centre of the sun and that of the earth. After this we have an account of the "spots," accompanied with tables of their numbers in different years, and their connection with the movements of the magnetic needle. The labours of Herschel, Airy, Lockyer, Huggins, and others are largely quoted, and the author begs any ob- 